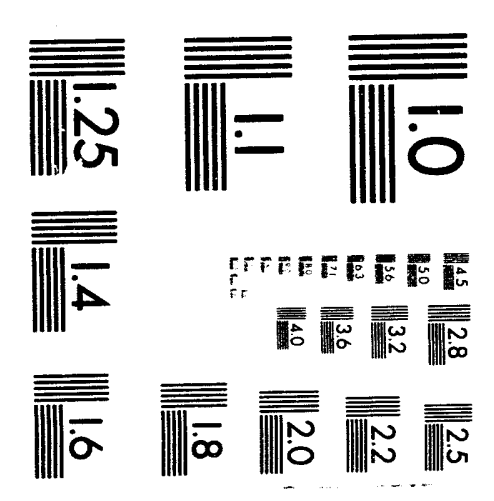



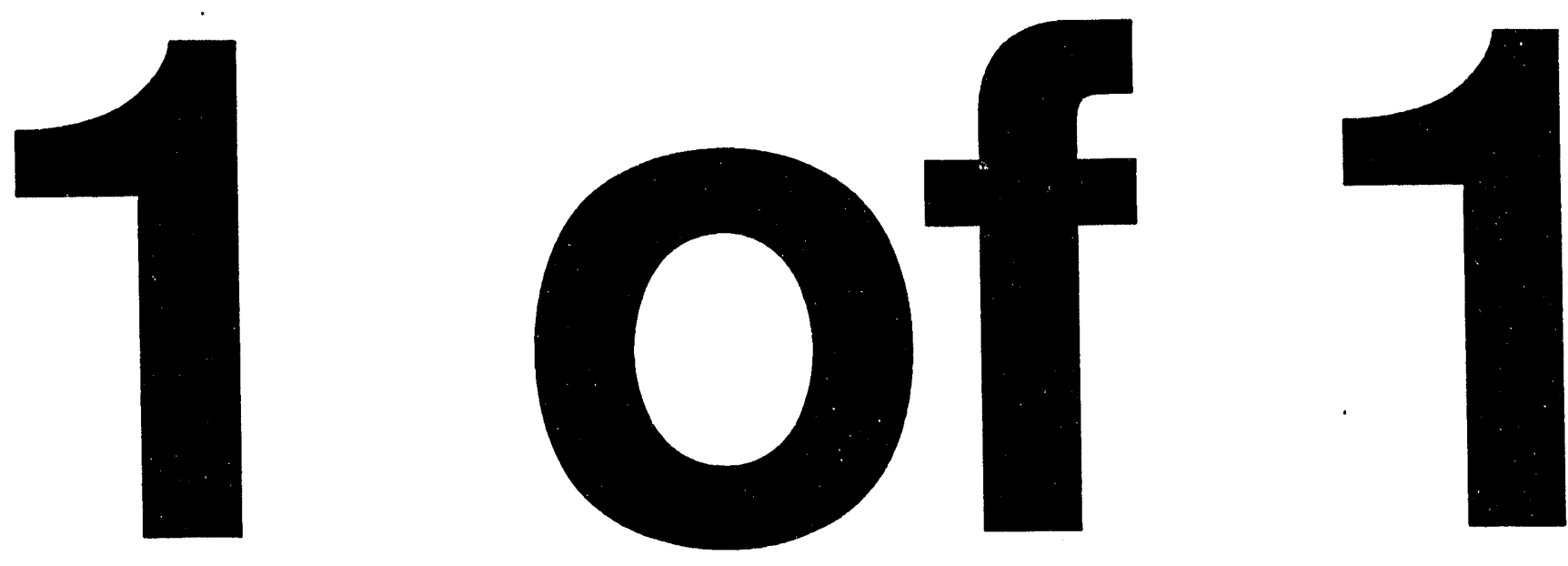


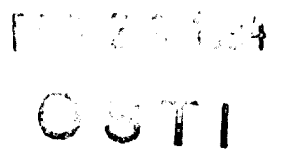

\title{
UMTRA Project Office Federal EMPLOYEE OCCUPATIONAL SAFETY And Health Program Plan
}

\author{
Final Draft
}

February 1994

\section{DISCLAIMER}

This report was prepared as an account of work sponsored by an agency of the United States This report was prepared as an account of work sponsored the United States Government nor any agency thereof, nor any of their employees, makes any warranty, express or implied, or assumes any legal liability or responsibility for the accuracy, completeness, or usefulness of any information, apparatus, product, or process disclosed, or represents that its use would not infringe privately owned rights. Referprocess disclosed, or represents to any specific commercial product, process, or service by trade name, trademark, manufacturer, or otherwise does not necessarily constitute or imply its endorsement, recommanufacturer, or otherwise or favoring by the United States Government or any agency thereof. The views and opinions of authors expressed herein do not necessarily state or reflect those of the United States Government or any agency thereof. 


\section{INTENDED FOR PUBLIC RELEASE}

This report has been reproduced from the best available copy. Available in paper copy and microfiche.

Number of pages in this report: 34

DOE and DOE contractors can obtain copies of this report from:

Office of Scientific and Technical Information

P.O. Box 62

Oak Ridge, TN 37831

(615) 576-8401

This report is publicly available from:

National Technical Information Service

Department of Commerce

5285 Port Royal Road

Springfield, VA 22161

(703) $487-4650$ 


\section{UMTRA PROJECT OFFICE \\ FEDERAL EMPLOYEE OCCUPATIONAL \\ SAFETY AND HEALTH PROGRAM PLAN}

Signature Page

Prepared by:

Date:

Bennett $H$. Young

UMTRA Environment, Safety, and Health Manager

Reviewed by:

Date:

Frank Bosiljevac

UMTRA Technical Support

Group Leader

Approved by:

Date:

Albert R. Chernoff

UMTRA Project Manager 


\title{
UMTRA PROJECT OFFICE FEDERAL EMPLOYEE OCCUPATIONAL SAFETY AND HEALTH PROGRAM PLAN
}

\author{
Final Draft
}

February 1994

Prepared for

U.S. Department of Energy UMTRA Project Office

Albuquerque, New Mexico

Prepared by Jacobs Engineering Group Inc.

Albuquerque, New Mexico 


\section{MANAGER'S STATEMENT}

All work activities under the auspices of the U.S. Department of Energy's Uranium Mill Tailing Remedial Action Project Office shall be conducted in a manner that ensures the safety and health of UMTRA Project federal employees, contractors, the general public, and visitors. Unsafe conditions shall be identified and promptly corrected, and appropriate measures shall be taken to eliminate recurrence. UMTRA Project federal employees and contractors shall strive for excellence in the area of safety and health during UMTRA Project operations. This will be accomplished by compliance with Occupational Safety and Health Administration regulations and the operating practices specified within DOE Order 5480.19, Conduct of Operations Requirements for DOE Facilities. Immediate correction of lifethreatening situations overrides all other priorities.

Albert R. Chernoff

UMTRA Project Manager

U.S. Department of Energy 


\section{TABLE OF CONTENTS}

Section

Page

1.0 UMTRA PROJECT OFFICE FEDERAL EMPLOYEE OCCUPATIONAL SAFETY

AND HEALTH PROGRAM $\ldots \ldots \ldots \ldots \ldots \ldots \ldots \ldots \ldots \ldots \ldots \ldots$

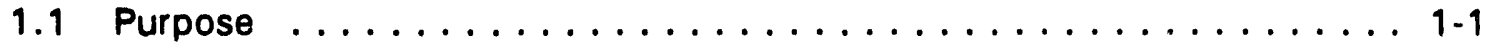

1.2 Scope ............................. 1-1

1.3 Responsibilities ......................... 1-2

1.3.1 UMTRA Project Manager . . . . . . . . . . . . . . 1-2

1.3.2 UMTRA group leaders . . . . . . . . . . . . . . . 1-2

1.3 .3 UMTRA ES\&H Manager ................. 1-3

1.3.4 Federal employees ................... 1-4

1.3.5 DOE-AL Equal Employment Officer . . . . . . . . . . . . 1-5

2.0 INSPECTION AND ABATEMENT PROCEDURES $\ldots \ldots \ldots \ldots \ldots \ldots \ldots$

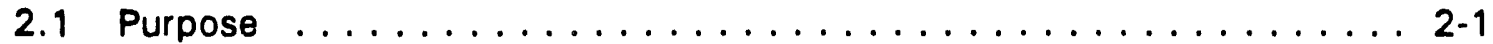

2.2 Responsibilities ......................... 2-1

2.3 Inspection procedures ...................... 2-1

2.4 Abatement and abatement plans . . . . . . . . . . . . . 2-3

2.5 Routine surveillance ....................... 2-4

3.0 FEDERAL EMPLOYEE REPORTING OF UNSAFE AND UNHEALTHFUL

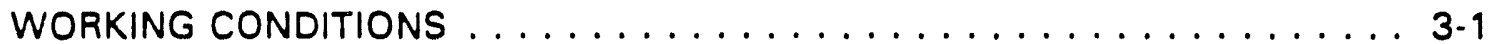

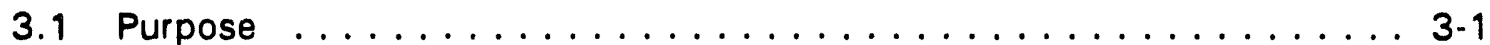

3.2 Responsibilities ........................ 3.1

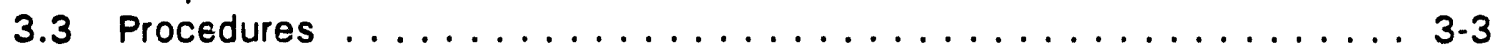

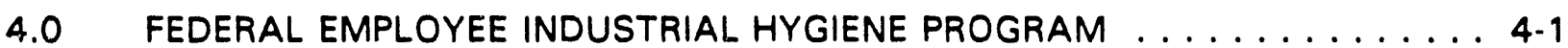

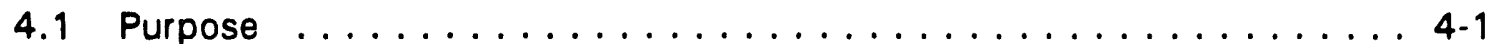

4.2 Responsibilities ........................ 4-1

4.3 Requirements and procedures ................. 4-1

4.3.1 Industrial hygiene staff ................. 4-1

4.3.2 Industrial hygiene program function ........... 4-1

4.3.3 Hazard identification and evaluation .............. 4-2

4.3.4 Control measures ......................4 4-2

4.3.5 Carcinogen control policy ................. 4-3

4.3.6 Periodic review ...................... 4.3

4.3.7 Education ...................... 4-3

4.3.8 Record keeping requirements . . . . . . . . . . . . 4-3

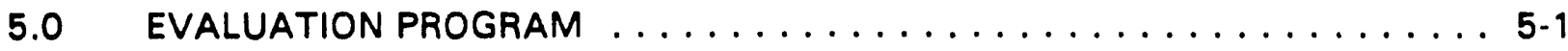

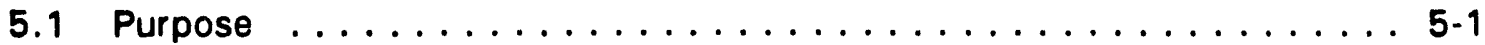

5.2 Responsibilities ......................... 5-1

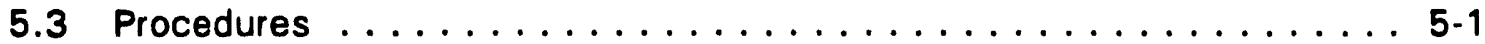


TABLE OF CONTENTS (Continued)

\section{Section}

Page

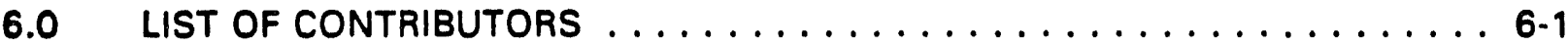

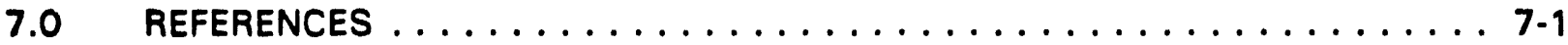




\section{LIST OF FIGURES}

Section

Page

2.1 Safety and health inspection guide for offices $\ldots \ldots \ldots \ldots \ldots \ldots \ldots$

3.1 UMTRA Project supervisor's FEOSH report $\ldots \ldots \ldots \ldots \ldots \ldots \ldots \ldots \ldots$ 


\section{LIST OF ACRONYMS}

\section{Acronym Definition}

$A L$

CFR

Albuquerque Operations Office

DOE

Code of Federal Regulations

ES\&H

U.S. Department of Energy

ES\&H

Environment, Safety, and Health

FEOSH

OSH

environmental, safety, and health

OSHA

PPE

RAC

Federal Employee Occupational Safety and Health occupational safety and health

TAC

Occupational Safety and Health Administration

personal protective equipment

UMTRA

remedial action contractor

Technical Assistance Contractor

Uranium Mill Tailings Remedial Action 


\subsection{UMTRA PROJECT OFFICE FEDERAL EMPLOYEE OCCUPATIONAL SAFETY AND HEALTH PROGRAM}

\subsection{PURPOSE}

This document establishes the Federal Employee Occupational Safety and Health (FEOSH) Program for the U.S. Department of Energy (DOE) Uranium Mill Tailings Remedial Action (UMTRA) Project Office. This program will ensure compliance with the applicable requirements of DOE Order 3790.1B and DOE Albuquerque Operations Office (AL) Order 3790.1A. FEOSH Program responsibilities delegated by the DOE-AL to the UMTRA Project Office by AL Order 3790.1A also are assigned.

The UMTRA Project Office has developed the UMTRA Project Environmental, Safety, and Health (ES\&H) Plan (DOE, 1992), which establishes the basic programmatic ES\&H requirements for all participants on the UMTRA Project. The ES\&H plan is designed primarily to cover remedial action activities at UMTRA sites, and defines the ES\&H responsibilities of both the UMTRA Project Office and its contractors. The UMTRA FEOSH Program described herein is a subset of the overall UMTRA ES\&H program and covers only the federal employees working on the UMTRA Project.

\subsection{SCOPE}

The UMTRA FEOSH Program is applicable to all federal employees at the UMTRA Project Office. Since the UMTRA Project Office, which is remotely located from the DOE-AL base complex, is collocated with the UMTRA Project Technical Assistance Contractor (TAC), the UMTRA FEOSH Program and the TAC's occupational safety and health (OSH) program will be integrated. However, the UMTRA Project Office will retain the responsibility for ensuring full compliance with the applicable requirements of DOE Order $3790.1 \mathrm{~B}$ and $\mathrm{AL}$ Order 3790.1A.

The UMTRA Project Remedial Action Contractor (RAC) is responsible for implementing the UMTRA ES\&H plan's requirements at UMTRA sites with active surface remedial action programs. All UMTRA Project federal employees are required to follow the RAC'S ES\&H plan, which has been approved by the DOEAL Contracting Officer, while at active sites. This UMTRA FEOSH Program Plan is primarily designed to cover federal employees in the office environment and at sites without active surface remedial action programs.

If more program elements are developed, they will be incorporated into revisions of this document and will become part of the UMTRA FEOSH Program. 


\subsection{RESPONSIBILITIES}

\subsubsection{UMTRA Project Manager}

The UMTRA Project Manager's responsibilities are as follows:

- Assigns an ES\&H Manager for the UMTRA Project Office who is responsible for establishing and maintaining the UMTRA FEOSH Program.

- Ensures an annual safety meeting to provide training in employee rights and responsibilities.

- Ensures that federal employees attend FEOSH training and are authorized official time to participate in the FEOSH Program.

- Ensures availability of safety equipment for employees.

- Ensures annual safety inspections at the UMTRA Project Office City Place work areas.

- Ensures prompt correction of unsafe or unhealthful working conditions and prompt reporting to the City Place building management of all building safety deficiencies not corrected.

- Ensures prompt investigation of employee complaints.

- Ensures provision in the TAC contract for support of the UMTRA FEOSH Program at the UMTRA ES\&H Manager's direction.

\subsubsection{UMTRA group leaders}

UMTRA group leaders' responsibilities are as follows:

- Ensure the establishment and maintenance of safe and healthful practices and work places within each area of responsibility.

- Ensure that employees are trained in safe practices applicable to their duties.

- Recognize and anticipate potential hazards.

- Inform employees of the proper procedures in carrying out work assignments and ensure employee compliance.

- Ensure that only qualified and properly trained employees are allowed to perform particular operations.

- Inspect work areas regularly to observe operations. 
- Enforce the UMTRA FEOSH Frogram, safety rules, safe work practices, and maintenance of safe conditions for their employees.

\subsubsection{UMTRA ES\&H Manager}

The UMTRA ES\&H Manager's responsibilities are as follows:

- Establishes and implements an OSH program for UMTRA Project federal employees, as defined in DOE Order 3790.1B, and ensures that the UMTRA FEOSH Program covers the following:

- Hazard communication.

- Office safety.

- Lockout/tagout.

- Construction safety.

- Vehicle safety.

- Industrial hygiene.

- Fire protection.

- Radiation safety.

- Ensures availability of the following information for UMTRA Project employees and employee representatives:

- DOE Order 3790.1B.

- Executive Order 12196.

- 29 CFR Part 1960.

- DOE safety and health program directives.

- Other applicable safety and health standards.

- Ensures at least annual formal safety and health inspections of UMTRA Project Office areas by the TAC; ensures more frequent inspections where an increased risk of accident, injury, or illness exists; and provides the UMTRA Project Manager with written reports of all formal inspections.

- Ensures immediate abatement of the hazardous condition in situations of imminent danger and, if necessary, the removal of employees from the vicinity who are not needed to correct the condition.

- Ensures close cooperation and coordination between DOE-AL OSH personnel and UMTRA Project employees.

- Accompanies DOE-AL Safety Programs Division inspectors on inspections of UMTRA Project work space, and ensures prompt attention to any resulting findings, observations, citations, and recommendations.

- Ensures operational and properly maintained fire protection and alarm systems and annual fire evacuation drills. 
- Evaluates planned changes to the UMTRA Project work space and informs federal employees of anticipated changes.

- Investigates employee complaints and reports of unsafe or unhealthful working conditions. Implements corrective actions for conditions not meeting safety and health standards.

- Ensures implementation and TAC maintenance of safety and health training programs for federal employees.

- Ensures implementation and TAC maintenance of a federal employee industrial hygiene program.

\subsubsection{Eederal emplovees}

Federal employees' responsibilities are as follows:

- Comply with federal and state safety and health regulations and safety or health practices and procedures specified by supervisor or the contractors controlling operations at UMTRA Project sites.

- Observe all safety and health rules and make maximum use of all prescribed personal protective equipment (PPE).

- Notify supervisor and, if appropriate, the contractor controlling operations at an UMTRA site immediately of exposure to harmful agents and of certain conditions or practices that may cause illness or injury.

- Perform work safely to avoid accidents.

- File a complaint under the grievance procedures described in DOE Order 3771.1 or under an applicable negotiated grievance procedure if it is believed that an act of reprisal or discrimination has been committed.

- Know primary and secondary exit routes from the City Place building and ensure that all persons, especially visitors, in their areas know the locations of the following:

- Exit routes.

- Fire alarm pull stations.

- Fire alarms.

Provide evacuation assistance to all persons in case of fire alarm or drill as per UMTRA Project's fire protection procedures. 


\subsubsection{DOE-AL Equal Employment Officer}

The DOE-AL Equal Employment Officer's responsibilities are as follows:

- Conducts investigation of discrimination complaints and, if necessary, issues orders for appropriate relief in accordance with DOE Order 3790.1B.

- Ensures that federal employees are not subject to restraint, interference, coercion, reprisal, or other discrimination if they participate in DOE's UMTRA FEOSH Program, to include filing reports describing an unsafe or unhealthful working condition or exercising other rights afforded by Section 19 of the Occupational Safety and Health Act (29 USC \$651), Executive Order 12196, and 29 CFR Part 1960. 


\subsection{INSPECTION AND ABATEMENT PROCEDURES}

\subsection{PURPOSE}

This section establishes responsibilities and prescribes procedures for formal inspections, routine surveillance, and hazard abatement in UMTRA Project Office areas.

\subsection{RESPONSIBILITIES}

- The UMTRA Project Manager shall provide for formal inspections of UMTRA Project Office areas and the resources for abating unsafe and unhealthful hazardous conditions.

- The UMTRA ES\&H Manager shall ensure formal inspections by qualified safety and health inspectors who meet the DOE Office of Personnel Management standards cited in 29 CFR $\$ 1960.2(s)$ or inspector qualifications defined in 29 CFR $\$ 1960.25(a)$.

- The UMTRA ES\&H Manager shall ensure the preparation, implementation, and prompt completion of abatement plans.

- Inspectors shall use checklists during formal inspections and document inspection results. The "Safety and Health Inspection Guide for Offices" (Figure 2.1) may be used to guide inspection planning of UMTRA Project Office space.

- UMTRA Project federal employees shall report any unsafe or unhealthful work practices identified in UMTRA Project Offices to the ES\&H Manager or group leaders.

\subsection{INSPECTION PROCEDURES}

- When appropriate to the scope of the inspection, the ES\&H Manager and inspectors shall meet with the City Place building management to explain the inspection purposes and request accompaniment by a building management representative.

- Inspectors shall have access to all pertinent records in the City Place building file prior to or during an inspection.

- The inspection shall be conducted during regular building working hours to minimize disruption of building operations.

- Employees shall have the opportunity to discuss potentially unsafe or unhealthful conditions in the work place. 
1. Fire Protection

a. Fire systems (detection, alarms, pull stations).

b. Fire extinguishers (inspected, operational, adequate).

c. Exit and emergency lights (visible, operational, properly positioned).

d. Emergency egress (no obstructions, posted escape routes, wide aisles).

e. Good housekeeping (trash disposed).

- Books/paper/printouts (properly stored).

- Flammable/combustible liquids (approved/labeled containers, properly stored, minimum quantities).

\section{Tripping Slipping and Falling Hazards}
a. Floors (clean, dry, unobstructed walkways).
b. Carpeting or floor covering (secured, not torn or curled).
c. Stairways (clean, handrails, antislip treads).
d. Extension cords (covered/taped, no tripping hazard crossing walking areas).
e. Ladders/stands (available for high files).
f. Desk and cabinet drawers (closed).

3. Equipment

a. First-aid kits (available, properly stocked).

b. Office layout (safe arrangement, clear walkways).

c. Furniture (good condition, properly used).

d. Cabinets/shelves (secured, properly loaded).

e. Doors (glass panels, warnings posted).

f. Associated hazards (properly labeled).

g. General equipment (properly guarded with covers/doors, protruding objects eliminated or guarded)

4. Electrical Hazards

a. Electrical equipment (UL approved, properly connected, no defects in cords/wiring, protected multioutlets, properly grounded).

5. Industrial Hygiene

a. Illumination (adequate lighting/shades, emergency lights).

b. Noise (sound enclosures for printers/copiers).

c. Sanitation (clean work/break areas).

d. Ventilation (adequate for copiers/temperature control).

e. Ergonomics (appropriate furniture/CRT glare, wrist rests).

f. Chemicals (material safety data sheets available, proper labeling).

FIGURE 2.1 SAFETY AND HEALTH INSPECTION GUIDE FOR OFFICES 
- Sampling of work environments shall be conducted if work practices or the building environment are suspected of creating unsafe or unhealthful working conditions. Appropriate methods shall be used.

- If unsafe or unhealthful conditions are found, they shall be brought to the attention of management. A closing conference will be conducted with project management, employees, and, if appropriate, the responsible building management personnel.

- Management and employees shall be notified of any unsafe or unhealthful conditions as soon as sampling results are known.

- If an imminent danger is determined, affected employees shall be protected immediately and responsible UMTRA Project and building management shall be informed.

- The inspectors shall submit documentation of each inspection to the UMTRA Project ES\&H Manager within 2 weeks of inspection completion.

\subsection{ABATEMENT AND ABATEMENT PLANS}

The abatement period shall be the shortest interval possible to correct a violation disclosed during an inspection.

- A written notice shall be conspicuously posted at or near each area where a hazardous working condition exists within 15 days of inspection or sampling completion. The written notice shall be posted until the condition has been abated or for 3 working days, whichever is longer.

- The notice shall include:

- The nature and extent of the unsafe or unhealthful working condition(s).

- A reference to the safety or health standard(s) violated.

- A reasonable deadline for abatement of the hazardous condition(s).

- The notice shall be provided to project management and affected employees.

- Project management shall prepare an abatement plan outlining the correction of unsafe and unhealthful working conditions that cannot be corrected within 30 calendar days. The plan shall:

- Explain the circumstances of the delay.

- Establish a reasonable time to complete abatement.

- Establish safety and health provisions to protect employees until abatement. 
- Building management shall be required to abate any unsafe or unhealthful conditions in accordance with the building lease and other applicable regulations.

- The UMTRA Project ES\&H Manager shall verify abatement of unsafe or unhealthful conditions identified during inspections.

\subsection{ROUTINE SURVEILLANCE}

When employees of the UMTRA FEOSH Program or contractor(s) detect unsafe or unhealthful working conditions during routine work, the conditions shall be corrected as soon as possible. Employees shall document the conditions and actions taken and notify the UMTRA Project ES\&H Manager or group leaders.

The UMTRA Project ES\&H Manager shall identify and direct the actions needed to correct unsafe or unhealthful conditions.

To ensure completion of corrective actions, follow-up inspections shall be conducted and documented at the UMTRA Project ES\&H Manager's direction. 


\subsection{FEDERAL EMPLOYEE REPORTING OF UNSAFE AND UNHEALTHFUL WORKING CONDITIONS}

\section{$3.1 \quad$ PURPOSE}

This section establishes a formal system for federal employees to report unsafe or unhealthful working conditions.

\subsection{RESPONSIBILITIES}

The UMTRA Project Manager shall:

- Ensure that federal employees report unsafe working conditions they believe to exist to their group leaders, the ES\&H Manager, DOE-AL, or the Occupational Safety and Health Administration (OSHA) without fear of discrimination or reprisal.

- Ensure timely investigation of employee complaints.

The UMTRA ES\&H Manager shall:

- Ensure availability of DOE OSH complaint forms, EV-628 or DOE F5480.4, for UMTRA Project federal employees.

- Investigate complaints of unsafe or unhealthful working conditions and ensure they are inspected, promptly abated, and documented.

UMTRA Project group leaders shall:

- Ensure that employees are informed of their rights and responsibilities to report unsafe or unhealthful conditions upon initial hire date and annually thereafter.

- Document any employee safety or health complaints on the "UMTRA Project Supervisors' FEOSH Report" form (Figure 3.1) promptly and forward it to the ES\&H Manager.

Federal employees shall:

- Note any unsafe or unhealthful condition, practice, or other hazard capable of causing illness or bodily injury.

- Notify their group leaders or the ES\&H Manager immediately if exposure to harmful agents occurs or if they detect conditions or practices that may cause illness or injury. 
1. Condition category: Injury Illness Fire Imminent danger Other

2. Name of person reporting condition:

Title:

Phone:

3. When and where was it discovered? Date:

Time: Location:

4. Describe condition:

5. Did anyone require medical treatment? Yes No Describe:

6. What caused the condition?

7. What corrective actions were taken?

8. When were corrective actions taken? Time:

Date:

9. Are other corrective actions required/recommended?

10. Who needs to take the corrective action(s)?

Supervisor's signature:

Date:

FIGURE 3.1 UMTRA PROJECT SUPERVISOR'S FEOSH REPORT 


\subsection{PROCEDURES}

Procedures to investigate UMTRA Project federal employee reports of unsafe or unhealthful working conditions are as follows:

- The UMTRA Project ES\&H Manager shall ensure the recording of each report by subject matter. Date, time, and location of each condition shall be maintained for each case recorded.

- Upon receipt of a report, an inspection shall determine the seriousness of the report. The timing of the inspection shall be as follows:

- Immediately for imminent danger conditions.

- Within 3 working days for potentially serious conditions.

- Within 20 working days for all other conditions.

- If, through normal management action and with prompt notification to employees, the hazardous conditions identified can be abated immediately, an inspection may not be necessary.

- Employees may file complaints by writing a memorandum to their supervisor on DOE Form EV-628 or DOE F5480.4 (Figure 3.2) or reporting verbally through the DOE Office of Inspector General Employee Hotline (1-800-541-1625). Supervisors shall use the "UMTRA Project Supervisors' FEOSH Report" (Figure 3.1) to document employee complaints.

- Written reports shall include the name of the employee or representative of the employee filing the report and shall be available to the reporting employee for review.

- If the employee filing a report requests anonymity, his or her identity shall not be revealed to anyone other than an authorized representative of the U.S. Department of Labor or such other person(s) as authorized by the employee.

- The employee or the representative of the employee shall receive a written response to the complaint within 15 days following an investigation. A copy of the response shall be provided to appropriate supervisory personnel in the area affected by the report.

- The UMTRA Project ES\&H Manager shall investigate complaints. The DOE may ask for assistance from outside resources but cannot delegate its authority to investigate. 


\subsection{FEDERAL EMPLOYEE INDUSTRIAL HYGIENE PROGRAM}

\subsection{PURPOSE}

This section establishes the requirements and guidelines to maintain an effective industriel hygiene program for UMTRA Project federal employees.

\subsection{RESPONSIBILITIES}

The UMTRA Project ES\&H Manager shall:

- Provide a federal employee industrial hygiene program in accordance with DOE Order 3790.18 and direct TAC support and maintenance of the program.

- Implement an ongoing hazard communication program.

- Make federal employees aware that they must:

- Observe all safety and health rules and use all PPE required to minimize exposure to harmful conditions.

- Notify supervisors immediately of exposures to harmful agents or conditions.

- Notify federal employees when planned changes to work areas or practices may impact the work environment.

\subsection{REQUIREMENTS AND PROCEDURES}

\subsubsection{Industrial hygiene staff}

TAC staff who meet the DOE Office of Personnel Management's qualifications for an industrial hygienist shall support the industrial hygiene program at the direction of the UMTRA Project ES\&H Manager.

\subsubsection{Industrial hygiene proaram function}

The industrial hygiene program's function is to preserve federal employee health and well-being. This will be accomplished, in part, by training employees to recognize, evaluate, and control hazardous exposures and stresses in the office work place as well as at UMTRA Project sites.

- At the UMTRA Project City Place office and at UMTRA Project sites without an active surface remedial action program, UMTRA Project federal employees shall follow the TAC industrial hygiene program. At sites with 
activs surface remedial action programs, the UMTRA Project RAC's industrial hygiene program shall be followed.

- Contractors shall be directed to notify affected federal employees and the ES\&H Manager promptly of personnel exposures exceeding existing standards.

\subsubsection{Hazard identification and evaluation}

The following procedures shall be implemented to deal with occupational health hazards:

- TAC industrial hygienists shall identify and document all potential health hazard areas by assessing current operations, conducting periodic inspections, reviewing available information, and reviewing proposed changes and/or new operations.

- Industrial hygienists must determine the extent of identified hazards by examining the work place and using established detection methods to take personnel and area exposure measurements.

- Potential occupational exposures shall be documented and evaluated regarding permissible exposure limits. When a potential health hazard is identified that has no assigned permissible exposure limit, an exposure guide shall be developed based upon the best available technical information to limit potential harmful exposure.

- Results of all health hazard evaluations shall be forwarded to medical personnel to assist them in developing an appropriate medical monitoring program.

\subsubsection{Control measures}

Control measures shall be used to minimize exposures to potential health hazards. Engineering controls shall be used to the maximum extent possible. Administrative controls and PPE shall be used to supplement engineering controls as appropriate.

The following control measures shall be implemented when engineering and administrative controls are not feasible or are inadequate to protect federal employees:

- When exposures to gas, vapor, fumes, or particulate hazards exceed established limits, respirators shall be used. When respirators are required, the UMTRA Project contractor's respirator program shall be followed. 
- When federal employees' exposure to noise exceeds an 8-hour, timeweighted average of 84 decibels, hearing protection shall be used. When hearing protection is required, the UMTRA Project contractor's hearing conservation program shall be followed.

\subsubsection{Carcinogen control policy}

Employee exposures shall not exceed existing applicable standards for carcinogens. Every effort shall be made to obtain a suitable substitute for carcinogens or minimize employee exposure by application of industrial hygiene principles.

\subsubsection{Periodic review}

Documented reviews of the industrial hygiene program shall be conducted periodically to maintain satisfactory conditions. The TAC industrial hygienist shall determine the type and frequency of these reviews and report to the UMTRA Project ES\&H Manager the continuing adequacy of controls or the need for additional control measures.

When monitoring is performed, federal employees shall be able to observe monitoring in their work areas for toxic chemicals or harmful physical agents and shall be given access to the results.

\subsubsection{Education}

The UMTRA Project ES\&H Manager shall ensure that federal employees are trained in the industrial hygiene program. At a minimum, federal employees visiting UMTRA Project sites shall be trained to recognize potential hazards associated with their work. The TAC shall provide periodic training to federal employees under the UMTRA Project ES\&H Manager's direction.

The training program shall meet the requirements of DOE Order 3790.1B, Chapter V. The UMTRA Project ES\&H Manager shall test federal employees at the end of formal training sessions to assess the training program effectiveness.

\subsubsection{Record keeping requirements}

Area walk-through surveys that result in noted deficiencies in the control of hazards, procedures, and violations shall be documented regarding the observation and the action taken. Deficiencies identified in formal compliance inspections shall be documented in accordance with Section 2.3.

The results of air sampling or other occupational monitoring data shall be documented. 
Evaluations for compliance or noncompliance with the standard(s) applicable to a particular situation shall be clearly documented. Actions taken due to noncompliance also shall be documented.

Employees shall have access to records in accordance with DOE Order 1324.2A. The TAC shall maintain the records for the UMTRA FEOSH Program as directed by the UMTRA Project ES\&H Manager.

Records access shall be provided to employees in accordance with 29 CFR $\$ 1910.20$, and all designated employee representatives must have written authorization.

UMTRA FEOSH training records shall include course content descriptions, attendance, records, and examination results. 


\subsection{EVALUATION PROGRAM}

\subsection{PURPOSE}

The evaluation program for the UMTRA FEOSH Program will be established in accordance with DOE Order 3790.1B.

\subsection{RESPONSIBILITIES}

The UMTRA Project Manager shall ensure internal evaluations of UMTRA Project safety and health programs at least once every 3 years in accordance with DOE Order 3790.1B.

The ES\&H Manager shall develop and implement an assessment of the UMTRA FEOSH Program and those portions of UMTRA Project contractor safety and health programs on which the FEOSH Program is dependent.

\subsection{PROCEDURES}

All factors identified in DOE Order 3790.1B, Chapter IX, Section 5, shall be considered when developing the evaluation program.

Qualified safety and health professionals shall conduct functional evaluations. 


\subsection{LIST OF CONTRIBUTORS}

The following individuals contributed to the preparation of this report.

\begin{tabular}{ll}
\hline Name & Contribution \\
\hline A. Vollmer & Overall document coordination \\
L. Ross & Document review \\
B. Young & Peer review \\
L. Keith, C. Slosberg & Text processing \\
& Graphic design \\
J. Torline, K. Walston & Technical editing \\
\hline
\end{tabular}




\subsection{REFERENCES}

DOE (U.S. Department of -nergy), 1992. UMTRA Project Environmental, Safety, and Health Plan, UMTRA-DOE/AL-150129.0000, prepared by the U.S. Department of Energy, UMTRA Project Office, Albuquerque Operations Office, Albuquerque, New Mexico.

\section{DOE ORDERS}

AL Order 3790.1A, Federal Employee Occupational Safety and Health Program, January 5, 1988, DOE Albuquerque Operations Office.

Executive Order 12196, Occupational Safety and Health Programs for Federal Employees, February 27, 1980, Office of the President.

Order 1324.2A, Records Disposition, September 13, 1988, U.S. Department of Energy.

Order 3771.1, Grievance Policy and Procedures, July 2, 1981, U.S. Department of Energy.

Order 3790.1B, Federal Employee Occupational Safety and Health Program, January 7. 1993, U.S. Department of Energy.

Order 5480.19, Conduct of Operations Requirements for DOE Facilities, U.S. Department of Energy.

\section{CODE OF FEDERAL REGULATIONS}

29 CFR Part 1910, Occupational Safety and Health Standards, Occupational Safety and Health Administration, 1993.

29 CFR Part 1960, Basic Program Elements for Federal Employee Occupational Safety and Health Programs, Occupational Safety and Health Administration, 1993.

\section{UNITED STATES CODE}

29 USC $\$ 651$ et seq., Occupational Safety and Health Act, 1993. 

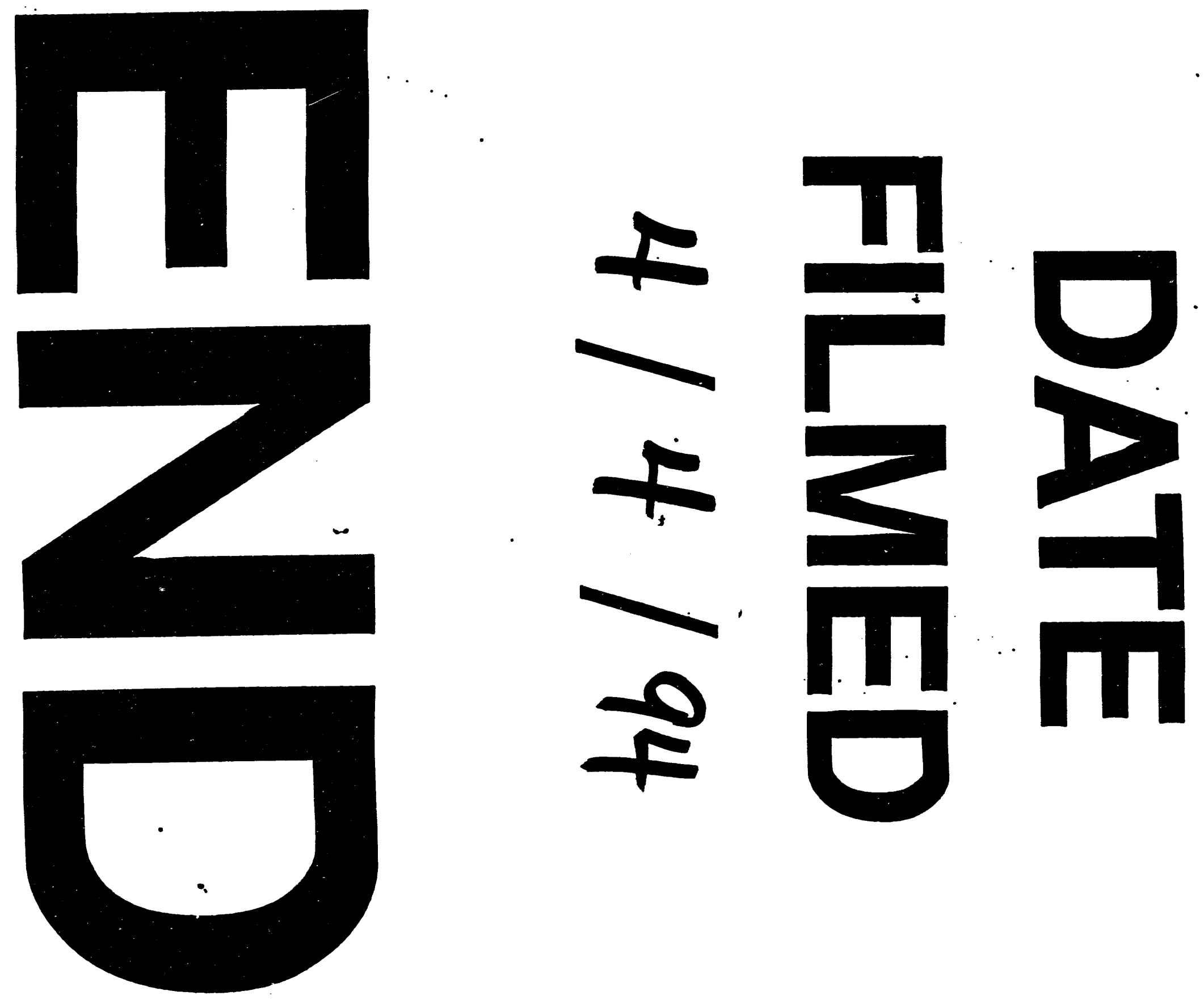
